Article Type: Research Paper

\title{
SOCIAL FUND AND THE HIERARCHY OF MUHAMMADIYAH ORPHANAGES FINANCIAL INDEPENDENCY
}

\author{
Yuli Utami ${ }^{1}$, Azmi Najmimudin Azhari ${ }^{2}$, Tjiptohadi Sawarjuwono ${ }^{1}$, and Abu \\ Azam Alhadi ${ }^{1}$
}

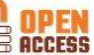

\begin{abstract}
AFFILIATION:
${ }^{1}$ Universitas Airlangga, Surabaya, Indonesia.

2 Universitas Muhammadiyah

Yogyakarta, Yogyakarta, Indonesia.
\end{abstract}

\section{*CORRESPONDENCE:}

yuli.utami-2015@pasca.unair.ac.id

THIS ARTICLE IS AVALILABLE IN:

http://journal.umy.ac.id/index.php/esp

DOI: 10.18196/jesp.20.2.5024

\section{CITATION:}

Utami, Y., Azhari, A. N., Sawarjuwono, T., \& Alhadi, A. A. (2019). Social Fund and The Hierarchy of Muhammadiyah Orphanages Financial Independency. Jurnal Ekonomi \& Studi Pembangunan, 20(2), 190206.

\section{ARTICLE HISTORY}

Received:

25 August 2019

\section{Accepted:}

27 October 2019

\begin{abstract}
This study aims to analyze the Muhammadiyah social fund and the hierarchy of financial independence of seven its orphanages in the Province of Daerah Istimewa Yogyakarta. This study utilizes primary data which is obtained from interview, questionnaire, document studies, and observations; and analyzed using Analytical Hierarchy Process and SWOT approaches. It finds that the orphanages have the same type of fund resources which collected from the donors, namely, permanent donor (the top priority), incidental, social service and government, permanent business, and seasonal business. Meanwhile, the orphanage funds were allocated to the foster children's skill improvement, foster children's tuition fee, orphanages development fund, orphanages activities, kitchen support/daily needs, orphanage's saving/investment and foster children's saving/investment. Four of out seven orphanage funds prior allocation went to the foster children's skill improvement, while the rest, to the orphanage development, foster children's saving/investment, and orphanage's saving/investment. It indicates the dependency of the orphanages financial sources toward the donors, or lacks their own investment, despite some are better-off by starting their ownbusiness. These finding could be benefited for the orphanages in managing the social funds for investment and mapping the potential as well as the development of the orphanage financial independence in their future strategies.
\end{abstract}

Keywords: Orphanage; Financial independence; Muhammadiyah; Social fund; AHP.

JEL Classification: L3; L31; J13; D64

\section{Introduction}

Financial funding for the orphanage is remained major problems faced by most of the developing countries, including Indonesia. A number of social institutions and philanthropy activities have been introduced and helped the government in many countries to solve the social problem of orphans and children displaced. However, there is no relation between the need and the resources in the case of most of the orphanages. This makes the progress of some institutions slow when compared with others. Well 
established institutions are ensured of the sustained flow of resources to them. But recent and "poor" institutions continue to be in a state of uncertainty concerning resources.

Problems of supporting network and financial management are also dominating the social reality in running the orphanage. Non-sustainability of revenue sources is the root of this problem. Their revenue has a high element of uncertainty and unpredictability. There is a general increase in the expenditure on all items due to the price increase of commodities. The increasing proportion of unproductive expenditure on items like transport, construction works, and non-specified others are also un-neglect-able.

These situations encourage Muhammadiyah, as one of the Islamic movement that has initiate orphanage institutions all around Indonesia, to utilize all domestic resources to overcome the problem of humanities and economy. The existence of theology Al-Ma'un as Muhammadiyah's foundation in serving the community in three areas of healing (health), schooling (education) and feeding (social security and philanthropy) are in this regard finds its significance (Qodir, 2008). By establishing an orphanage on waqf land, orphans, and displaced children will get a decent shelter, affections, food, and access to education freely (Abror, 2012; Rizki, 2018).

However, one crucial issue that must be further discussed in evaluating program successes and failures is the concept of funding for the orphanage itself. Funding from Muhammadiyah and donors is judged by meeting needs alone. On the contrary, the problem arises because the source of funding for the orphanage is very dependent on various sources of social grants that are not fixed so it tends to face financial difficulties if the budget expenditure is greater than the source of incoming funds.

Therefore, the presence of economic independence status for the orphanage that accommodates sustainability revenue source is highly needed (Silvia, 2018). Regarding this issue, this paper would like to analyze the economic potential funding-sources hierarchy that can be built by the orphanages Muhammadiyah-Yogyakarta, that are never been research before. Hence, the research useful to measure their financial independence and predict their strength future plans strategy.

This paper comprises five sections with an introduction as the first one. The theoretical framework will be discussed in the second section, followed by research methodology in the third section. The fourth section will elaborate on the findings and analysis while the last section concludes the paper.

This paper is a pioneer study undertaking an empirical investigation on the hierarchy of the financial independence of orphanages. Therefore, the theory will use in this study will depend on the observation and the way its interpretation.

\section{Muhammadiyah and Social Fund}

Muhammadiyah is known as an Islamic renewal organization with a modern pattern. In practice, Muhammadiyah believes in the Al-Qur'an and Al-Sunnah Rasulullah as its source. 
The interpretation of the Al-Quran and Al-Sunnah is revealed at the level of praxis, and translated into a real movement. The rampant charity of Muhammadiyah, AUM (Amal Usaha Muhammadiyah), is a manifestation of the belief of the Muhammadiyah founding father KH. Ahmad Dahlan from Quran Surah Al Ma'un (Verse 1-7). His interpretation was later known as Al-Ma'un Theology (Susanto, 2106).

The virtue of sponsoring orphans encourages the Muhammadiyah to provide real action by establishing various businesses, better known as the Muhammadiyah Business Charity (AUM) (Muhammadiyah, 2016), which is interpreted into three main activities of schooling, healing and feeding (Qodir, 2008). In other words, transforming a religious understanding of mere sacred doctrines and less socially sounds becomes cooperative for human liberation. The education obtained at the orphanage at least provides enough stock for orphans to live independently in the future so that it can reduce the burden of the government and the unemployment rate, as well as the number of alliterations.

The Central office Muhammadiyah, through the Assembly of Social Services (MPS) and Muhammadiyah Zakah, Infaq, Shadaqah Institution (LAZISMU) PP Muhammadiyah launched the idea for strengthening children and family empowerment in 400 Muhammadiyah-Aisiyah institutions-all around Indonesia (Rizki, 2012). MPS and LAZISMU PP Muhammadiyah established a Child Center Indonesia in order to revitalize the role of orphanages and efforts to fulfill the fundamental rights of children.

The strategic plan of care pattern is given priority to the $\mathrm{CCl}$ projections; therefore, it is not only a sheltered place or residential children but as a provision and preparation place that will be very useful for foster children (Huttman \& Redmond, 1992). The program also pays attention to other aspects such as social services, economy, and children's education and family benefits that their children are in the orphanage. The programs also have undertaken lead to the strengthening of the family of the orphanage in the hope of being economically self-sufficient and developing an orphanage in order the children have full rights as if to be with his own family. In addition to focusing on the development of an orphanage, the program will also change the paradigm of parenting care to family-based care. Instead of focusing on the child alone, but it actually rather providing assistance to vulnerable families onto improving economic capacity and parenting skills

\section{Ecological System Theory, Power Dependency Theory, AHP and SWOT Analysis}

Developed by psychologist Urie Bronfenbrenner, ecological systems theory explains how different types of environmental systems influence human development, i.e., the (1) micro-, (2) meso-, (3) exo-, and (4) macro systems. These levels range from smaller, proximal settings in which individuals directly interact to larger, distal parameters that indirectly influence development. The various levels within ecological systems theory are often presented graphically as a series of four systems nested around a focal individual like a set of concentric circles (Andrea \& Mahoney, 2017). These levels will describe reality and provide full information in social research. 
Power is the key concept to understand the empowerment process. The purpose of power is to prevent the participation of other groups in the decision-making process and also to obtain passive group approval. Power is an integral part of social interaction. Power is a feature that is inseparable from social life. This is always part of the relationship, and signs that can be seen even at the level of micro-interaction.

Community development needs to pay attention to equality, conflict, and power relations or if not, and the success rate is low. After the failure of modernization, the theory the dependency theory came. The dependency theory in principle describes the existence of a relationship between unequal countries, especially between developed (central) and peripheral (non-developed) countries. There was an understanding of balance and equality, which in turn forms empowerment in community participation known as the theory of justice (Suparno, 2017). For example, the "power-dependency" theory tells us that donors (donors) gain power by giving money and goods to people who cannot reciprocate. This gives the idea that non-profit organizations (NGOs) should not receive funds from only one donor if they want to be independent (free).

The Analytical Hierarchy Process (AHP) is a decision-aiding method which has received increasing attention in the literature and application since its development by Saaty (Harker, 1987). Analytic Hierarchy Process (AHP) is a model used to facilitate decision making developed by Thomas L. Saaty. Decision model described in the form of a multifactor or complex multi-criteria become a hierarchy (Yüksel, 2012). The hierarchy is defined as a representation of a complex problem within a multilevel structure. Analytic Hierarchy Process is one of several analytical tools or methodologies in the decisionmaking process (Dona, 2017). Included are rational and intuitive factors for determining the best option. In determining the choice should be based on the criteria that have been considered and grouped according to hierarchy.

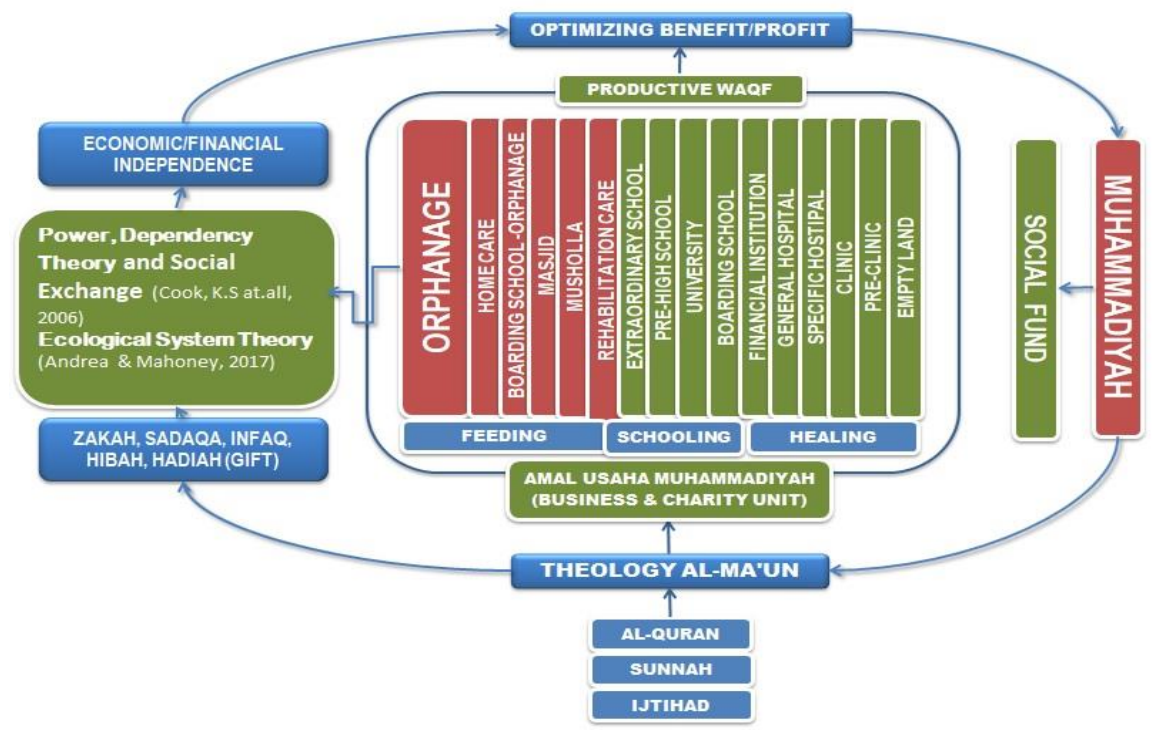

Figure 1 Conceptual Framework

Source: Author 
SWOT is a classical strategic planning tool that helps so much to find a way to assess the best strategy can be implemented. This tool helps planners think realistic about the achievement they can get and where they should focus on. SWOT analysis is an analytical technique that can be done by an organization in deciding a decision to achieve rapid growth in the future. The process involves the identification of strengths and weakness of the organization, the opportunities, and threats to the market in which the organization is engaged. SWOT analysis explains everything that can and cannot be done in business, as well as its potential opportunities and threats (Ommani, 2011).

\section{Research Method}

This study is mixed method research utilizes primary data which is obtained from an indepth interview, questionnaire, document studies, and observations. Qualitative research is an activity that puts the observer in social reality (Cresswell, 2007). It consists of a set of interpretive, material practices that make the world visible. These practices transform the world into representable social reality. It means that qualitative researchers study things in their natural setting, attempting to make sense of, or interpret the phenomena in a term of the meanings of people. The qualitative researcher should empathize and identify the people they study in order to understand and to know deeply how those people see all those things (Taylor, Bogdan, \& Devault, 2016). The technique to maintain data validity will take some steps as follows: extension of observation, Increased and lastly, do a triangulation technique (Lexy, 2009).

Several problems in management sometimes have contained qualitative and subjective criteria. The stakeholders can be influenced by other one decision, making it important to combine the criteria in decision-making. Thomas Saaty introduced a tool in 1970's i.e. the Analytic Hierarchy Process (AHP) that can incorporate multiple quantitative and qualitative criteria in a meaningful and rational way (Teehankee, 2009). Assessment or weighting in the hierarchy aims to compare the scores on each criterion to achieve the goal. Therefore, it will be obtained weighting the level of importance of each of the criteria to achieve the goals set. The pairwise comparison appraisal procedure in AHP refers to the scoring score developed by Thomas L Saaty (Saaty, 2001).

Analytical hierarchy process in this research uses data obtained from seven respondents i.e., Panti Asuhan Muhammadiyah Wates, Panti Asuhan Muhammadiyah Tuksono, Panti Asuhan Muhammadiyah Nanggulan, Panti Asuhan Muhammadiyah Seyegan, Panti Asuhan Yatim Putri Aisyiyah, Panti Asuhan Ahmad Sudjari, and Panti Asuhan Yatim Dhuafa Muhammadiyah Prambanan at D.I. Yogyakarta province. The data obtained is processed initially before input into Expert Choice 11 software. The first phase analysis is comparing the priority scale in the criteria to determine either the priority in the allocation of funds used by the orphanage or fund resource priority they got from the donors. 
Table 1 The Fundamental Scale of Absolute Numbers

\begin{tabular}{|c|c|c|}
\hline $\begin{array}{l}\text { Intensity of } \\
\text { Importance }\end{array}$ & Definition & Explanation \\
\hline 1 & Equal importance & $\begin{array}{l}\text { Two activities contribute equally to the } \\
\text { objective }\end{array}$ \\
\hline 2 & Weak or slight & \\
\hline 3 & Moderate importance & $\begin{array}{l}\text { Experience and judgement slightly favour one } \\
\text { activity over other }\end{array}$ \\
\hline 4 & Moderate plus & \\
\hline 5 & Strong importance & $\begin{array}{l}\text { Experience and judgement stongly favour one } \\
\text { activity over other }\end{array}$ \\
\hline 6 & Strong plus & \\
\hline 7 & $\begin{array}{l}\text { Very strong or demonstrated } \\
\text { importance }\end{array}$ & $\begin{array}{l}\text { An activity is favoured very strongly over } \\
\text { another, its dominance demonstrated in } \\
\text { practice }\end{array}$ \\
\hline 8 & Very, very strong & \\
\hline 9 & Extreme importance & $\begin{array}{l}\text { The evidence favouring one activity over } \\
\text { another is of the biggest possible order of } \\
\text { affirmation }\end{array}$ \\
\hline $\begin{array}{l}\text { Reciprocals } \\
\text { of above }\end{array}$ & $\begin{array}{l}\text { If activity I has one of the above } \\
\text { non-zero numbers assigned to } \\
\text { it when compared with activity } \\
j \text {, then } j \text { has the reciprocal value } \\
\text { when compared with I }\end{array}$ & A reasonable assumption \\
\hline $1.1-1.9$ & If the activities are very close & $\begin{array}{l}\text { May be difficult to assign the best value but } \\
\text { when compared with other contrasting } \\
\text { activities the size of the small numbers would } \\
\text { not noticcable, yet they can still indicate the } \\
\text { relative importance of the activities }\end{array}$ \\
\hline
\end{tabular}

This study also uses a SWOT analysis that provides weighting assessments from the Summary of Internal Factor Analysis (IFAS) and the Summary of External Factor Analysis (EFAS). IFAS and EFAS are used to produce the SWOT Matrix (Wahyuningtias, Sudarmiatin, Indrawati, 2016). The procedure that must be followed in this approach is first, identifying internal factors (interviewing orphans, teachers, supervisors, and also the top management of the orphanage). Secondly, is identifying external factors, namely by interviewing the nearest community, Muhammadiyah management, customers (orphans), as well as the government and donors. This data is used to identify opportunities and threats. Third, is gathering data on internal and external factors by weighing and ranking the strengths and weaknesses of each orphanage, so that we can determine the total score of strengths, weaknesses, opportunities, and threats. Fourth, analyze these data using the SWOT Matrix Diagram and plotted in the first quadrant (aggressive strategy), second quadrant (conservative strategy), third quadrant (defense strategy), and fourth quadrant (competitive strategy). 
Table 2 Rating Guidance for IFAS and EFAS

\begin{tabular}{lcc}
\hline Factors & Rating & Meaning \\
\hline Strength and opportunity & 1 & Outstanding \\
& 2 & Good \\
Threat and weakness & 3 & Fair \\
& 4 & Poor \\
& -1 & Not so good \\
& -2 & Fairly bad \\
& -3 & Warning \\
\hline
\end{tabular}

\section{Result and Discussion}

Sources of funds became one of the important factors in the development of orphanages. Sources of funds can be from anyone or party who has good intentions to help the orphanage in providing a decent life to foster children, at least to provide for all the needs of foster children even though it is not yet feasible. Funds obtained can be sourced from permanent or incidental donors. Not only that, the role of social services and the government is also very much needed in providing financial assistance to orphanages. Orphanages that already have a business, whether permanent or seasonal, it will be a source of funds that can be expected every day.

\section{Fund Allocation Priority}

Table 3 indicates that 4 of out 7 orphanages prioritized the use of funds to improve foster skills. Those orphanages are Panti Asuhan Ahmad Sudjari, Panti Asuhan Muhamadiyah Tuksono, Panti Asuhan Yatim Putri Aisiyah, and Panti Asuhan Yatim Dhuafa Prambanan. It seems that foster children's future is the main target priority of some orphanages. The orphanage provides the foster children to go to school, and all the tuition fee will be covered by the orphanage. What foster children to do are only study and utilize the facilities to support their future living opportunity. The reason orphanages focus on foster children's skill improvement is for their better preparation when they no longer occupy in the orphanage as delivered by $1 \mathrm{st} \mathrm{KI}$, in following statement:

"Q: How does important foster children's skill improvement?"

"A: According to us, it is very important, especially for their future. They can use it after they graduate the school for their living". (1st KI, July 2018).

The orphanage MuhammadiyahWates allocates funds for orphanage development as its main priority. By having several building as multipurpose building that can be rented for weddings, meetings and others, they can generate more incomes and have better and sustainable flows of resource. The donors are advice the orphanage to build a multipurpose building in order to get additional fund for fulfilling their daily needs. The construction was built in the beginning of 2015 and launched in the end of 2017. 
Table 3 Orphanages Fund Allocation Priority

\begin{tabular}{|c|c|c|c|c|c|c|c|c|c|}
\hline \multirow[t]{2}{*}{ No } & \multirow[t]{2}{*}{ Orphanages } & \multicolumn{8}{|c|}{ The criteria of priority } \\
\hline & & $\begin{array}{l}\text { Foster } \\
\text { childre } \\
\text { n's skill } \\
\text { improv } \\
\text { ement }\end{array}$ & $\begin{array}{l}\text { Foster } \\
\text { children's } \\
\text { tuition } \\
\text { fee }\end{array}$ & $\begin{array}{l}\text { Orphana } \\
\text { ges } \\
\text { develop } \\
\text { ment } \\
\text { fund }\end{array}$ & $\begin{array}{l}\text { Orphan } \\
\text { ages } \\
\text { activiti } \\
\text { es }\end{array}$ & $\begin{array}{l}\text { Kitchen } \\
\text { support } \\
\text { (consumpti } \\
\text { on) / daily } \\
\text { needs }\end{array}$ & $\begin{array}{l}\text { Orphana } \\
\text { ge's } \\
\text { saving / } \\
\text { investme } \\
\text { nt }\end{array}$ & $\begin{array}{l}\text { Foster } \\
\text { children's } \\
\text { saving } \\
\text { investment }\end{array}$ & / \\
\hline 1 & $\begin{array}{l}\text { Panti Asuhan } \\
\text { Muhammadiya } \\
\text { h Wates }\end{array}$ & 5 & 3 & 1 & 4 & 2 & 6 & 7 & \\
\hline 2 & $\begin{array}{l}\text { Panti Asuhan } \\
\text { Muhammadiya } \\
\text { h Tuksono }\end{array}$ & 1 & 5 & 6 & 4 & 7 & 3 & 2 & \\
\hline 3 & $\begin{array}{l}\text { Panti Asuhan } \\
\text { Muhammadiya } \\
\text { h Nanggulan }\end{array}$ & 3 & 7 & 4 & 5 & 6 & 2 & 1 & \\
\hline 4 & $\begin{array}{l}\text { Panti Asuhan } \\
\text { Muhammadiya } \\
\text { h Seyegan }\end{array}$ & 7 & 6 & 4 & 5 & 3 & 1 & 2 & \\
\hline 5 & $\begin{array}{l}\text { Panti Asuhan } \\
\text { Ahmad Sudjari }\end{array}$ & 1 & 6 & 2 & 7 & 5 & 3 & 4 & \\
\hline 6 & $\begin{array}{lr}\text { Panti } & \text { Asuhan } \\
\text { Yatim } & \text { Putri } \\
\text { Aisyah } & \end{array}$ & 1 & 3 & 4 & 2 & 7 & 6 & 5 & \\
\hline 7 & $\begin{array}{l}\text { Panti Asuhan } \\
\text { Yatim Dhuafa } \\
\text { Prambanan }\end{array}$ & 1 & 6 & 5 & 2 & 7 & 3 & 4 & \\
\hline
\end{tabular}

Source: Author

".....this building just launched last year (end of 2017) and use it as multipurpose building and we rent it. We got money to develop orphanage......mmm...and all are due to the donors advices". (4th KI, May 2018)

Panti Asuhan Muhammadiyah Wates is also undertaking renovations the female dormitories this year. It is expected to be completed by the end of the year. It is such the daily costs will be covered by the income generated from the businesses created by the orphanage. Following statement is the reason why Panti Asuhan Muhamadiyah Wates allocates more funds for orphanage development as stated by the 4th $\mathrm{KI}$ in an interview a few months ago:

"Maintenance cost, rehabilitation cost, and other costs will not possibly and sufficient if we see our budget.... However, Alhamdulillah, praises Allah, we can fulfill the entire budget. The physical building and the children development cost are all fulfilled". (4th KI, May 2018).

\section{Orphanages Fund Resources Priority}

The sources of funds became one of the important factors in orphanages development. Sources of funds can be from anyone and any party who has good intentions to help the orphanage in providing a decent life of foster children, at least to provide for all the needs of foster children, even though it is not feasible yet. Funds obtained can be the source came from permanent or incidental donors. The role of social services and the government is also very much needed in providing financial assistance to orphanages. 
Orphanages that already have a business, whether permanent or seasonal, will be a source of funds that expected to cover daily need.

Table 4 Orphanages Fund resources priority

\begin{tabular}{|c|c|c|c|c|c|c|c|c|c|c|c|c|c|c|c|c|c|c|c|c|c|c|c|c|c|c|c|c|c|c|c|c|c|c|c|c|}
\hline \multirow[t]{4}{*}{$\begin{array}{l}N \\
0\end{array}$} & \multirow[t]{4}{*}{ Orphanages } & \multicolumn{5}{|c|}{$\begin{array}{l}\text { Foster children's skill } \\
\text { improvement }\end{array}$} & \multicolumn{5}{|c|}{$\begin{array}{l}\text { Foster children's tuition } \\
\text { fee }\end{array}$} & \multicolumn{5}{|c|}{$\begin{array}{l}\text { Orphanages } \\
\text { development fund }\end{array}$} & \multicolumn{5}{|c|}{$\begin{array}{l}\text { Orphanages } \\
\text { activity }\end{array}$} & \multicolumn{5}{|c|}{$\begin{array}{l}\text { Kitchen support } \\
\text { (consumption)/ daily } \\
\text { needs }\end{array}$} & \multicolumn{5}{|c|}{$\begin{array}{l}\text { Orphanages } \\
\text { saving/ investment }\end{array}$} & \multicolumn{5}{|c|}{$\begin{array}{l}\text { Foster children's } \\
\text { saving/ investment }\end{array}$} \\
\hline & & PD & 1 & & P & S & P & I & $S$ & p & $S$ & $P$ & 1 & s & P & s & P & & s & & s & $\begin{array}{l}P \\
P\end{array}$ & & $s$ & $P$ & S & $P$ & 1 & S & p & $S$ & P & 1 & S & & \\
\hline & & & & s & B & B & D & & s & B & B & D & & s & B & B & D & & $s$ & 3 & B & D & & $s$ & B & B & D & & s & B & B & D & & s & B & \\
\hline & & & & $G$ & & & & & G & & & & & $G$ & & & & & G & & & & & G & & & & & G & & & & & G & & \\
\hline 1 & $\begin{array}{l}\text { Panti Asuhan } \\
\text { Muhammadiya } \\
\mathrm{h} \text { Wates }\end{array}$ & 1 & 2 & 3 & 4 & 5 & 1 & 3 & 2 & 5 & 4 & 2 & 1 & 3 & 4 & 5 & 1 & 3 & 2 & 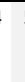 & 5 & 1 & 2 & 3 & 4 & 5 & 3 & 2 & 1 & 4 & 5 & 3 & 2 & 1 & 4 & 5 \\
\hline 2 & $\begin{array}{l}\text { Panti Asuhan } \\
\text { Muhammadiya } \\
\text { h Tuksono }\end{array}$ & 4 & 5 & 1 & 3 & 2 & 2 & 3 & 5 & 1 & 4 & 3 & 5 & 1 & 4 & 2 & 4 & 5 & 3 & ? & 1 & 15 & 5 & 4 & 3 & 2 & 2 & 5 & 4 & 3 & 1 & 4 & 5 & 3 & 2 & 1 \\
\hline 3 & $\begin{array}{l}\text { Panti Asuhan } \\
\text { Muhammadiya } \\
\text { h Nanggulan }\end{array}$ & 1 & 4 & 5 & 3 & 2 & 2 & 5 & 4 & 3 & 1 & 1 & 5 & 4 & 3 & 2 & 2 & 5 & 4 & 1 & 3 & 52 & 2 & 4 & 3 & 1 & 5 & 3 & 1 & 4 & 2 & 1 & 5 & 4 & 3 & 2 \\
\hline 4 & $\begin{array}{l}\text { Panti Asuhan } \\
\text { Muhammadiya } \\
\text { h Seyegan }\end{array}$ & 5 & 4 & 2 & 1 & 3 & 5 & 4 & 3 & 2 & 1 & 5 & 4 & 3 & 2 & 1 & 4 & 5 & 2 & 3 & 1 & 12 & 2 & 3 & 5 & 4 & 5 & 4 & 2 & 3 & 1 & 5 & 3 & 4 & 2 & 1 \\
\hline 5 & $\begin{array}{l}\text { Panti Asuhan } \\
\text { Ahmad Sudjari }\end{array}$ & 1 & 5 & 4 & 3 & 2 & 1 & 4 & 5 & 3 & 2 & 3 & 5 & 4 & 2 & 1 & 4 & 5 & 2 & t. & 3 & 5 & 3 & 4 & 1 & 2 & 4 & 5 & 2 & 1 & 3 & 3 & 5 & 4 & 1 & 2 \\
\hline 6 & $\begin{array}{l}\text { Panti Asuhan } \\
\text { Yatim Putri } \\
\text { Aisyah }\end{array}$ & 1 & 5 & 4 & 2 & 3 & 2 & 5 & 4 & 1 & 3 & 2 & 4 & 5 & 1 & 3 & 2 & 5 & 3 & 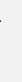 & 4 & 2 & 3 & 4 & 1 & 2 & 2 & 5 & 3 & 1 & 4 & 5 & 2 & 3 & 1 & 4 \\
\hline 7 & $\begin{array}{l}\text { Panti Asuhan } \\
\text { Yatim Dhuafa } \\
\text { Prambanan }\end{array}$ & 4 & 5 & 3 & 2 & 1 & 4 & 5 & 3 & 1 & 2 & 4 & 3 & 5 & 1 & 2 & 4 & 5 & 3 & t. & 2 & 3 & 5 & 4 & 1 & 2 & 5 & 4 & 3 & 2 & 1 & 4 & 5 & 3 & 2 & 1 \\
\hline
\end{tabular}

Note: BT (Permanent Business), I (Insidental donor), SSG (Social service and government), PD (Permanent donor), and SB (Seasonal business).

Table 4 shows that every criterion or program carried out by an orphanage has a dominant source of funds. The criteria for foster children's skill improvement are mostly funded by the permanent donor. It is happened in Panti Asuhan Muhammadiyah Prambanan, Panti Asuhan Muhammadiyah Tuksono, Panti Asuhan Muhammadiyah Wates, and PantiAsuhan Ahmad Sudjari. Permanent donors are still dominant as the foster children's skill improvement funding source. Though, the program funds sometimes also taken from incidental donors.

Foster children's tuition fee in Panti Asuhan Muhammadiyah Wates and Panti Asuhan Yatim Dhuafa Muhammadiyah Prambanan were obtained mostly from the contribution of the permanent donor. Sometimes, the donors in Panti Asuhan Muhammadiyah Wates were maintaining the budget plan and its purposes. On the other hand, Panti Asuhan Muhammadiyah Wates gets more dominant funds mostly from Social Service Government Agencies for foster children's saving and investment. The Social Agency mandates the funds given specifically for foster children's saving and other activities such as tuition fees, or others. This was mentioned by the 4 th $\mathrm{KI}$ in the following interview:

"Government social service usually donates their fund for children saving investment or for special purposes for example tuition fee or school fee." (4th KI, May 2018).

The Analytical Hierarchy Process analyzed that PantiAsuhanMuhamadiyahTuksono is also mostly gets funding from the KulonProgo Social Government Agency. However, the government aids (social government agency aids), will allocate for secondary supporting 


\section{Utami, Azhari, Sawarjuwono, \& Alhadi \\ Social Fund and The Hierarchy of Muhammadiyah Orphanages Financial Independency}

school fee due to the limited amount contributed. It is as exposure by the $1 \mathrm{st} \mathrm{KI}$, the orphanage secretary:

"Social Government Agency aids usually allocate as schooling fee or to buy school stuff. In fact, the aids are annual aids from the Government (Social Agency) for tuition fee. However, the amount will only enough for buying the schooling stuff, which around Rp.1,000,000,- per child. This amount will not cover all their current schooling cost. If they went to the elementary level in Indonesia (SD \& SMP), they will not pay the tuition fee, but in High School level (SMA) they have to. For those children went to the Muhammadiyah School, they will get a tuition fee reduction. Though, living in a same organization of Muhammadiyah, we still have to contribute to the unit business of Muhammadiyah. Therefore, the tuition fee reduction will mean so much to us. The government school is also giving the reduction fee for the orphans through local government budget. If each of them got Rp.1000K, the $900 \mathrm{~K}$ will give to the orphan and the rest (100K) will send for the schooling operation." (1st KI, May 2018).

The dominant orphanages' development fund of Panti Asuhan Muhammadiyah Tuksono mostly derived from the permanent donors and permanent businesses they have. The poor financial condition forced the staff and administrators of the orphanage work hard to raise funds since the first its opening. The 2006 Earthquake have destroyed the pioneers building of the orphanage. Since then, they work harder to collect the funds for renovation by sending proposals for funds to agencies, governments, and individual who has high social life. To cover the considerable cost of development, Panti Asuhan Muhammadiyah Tuksono is assisted by the business they run such LPG gas stations and refills of mineral water. The profits are used to cover the shortage of development costs and fulfill their daily needs. This was conveyed by the respondent (1st KI) in an interview a few months ago. Here's his exposure:

"...... slowly but sure, we collect several sources of fund to continue the renovations and build a new dormitory. If we have remained rice from ZakahFitr which was not finish to consume within a month, we will sell it for revenue. It is use as renovation fund, which the process is still under construction. The aids come from local Government, central and local PersyarikatanMuhammadiyah (PP and PDM) and individual donors. To develop new dormitory, we proposed government local budget plan that allocate for social purposes." (1st KI, May 2018)

Here is the statement given by the respondent relates to the business they are running in:

“......Praise to Allah, we have been signing a collaboration business contract since 2015 . We have LPG gas stations and refills of mineral water. The income still around Rp.100,000 - Rp.200,000 per month".( 1st KI, May 2018).

The basic need of the orphanage that may crucial to fulfill is the daily need such as food, cloth and shelter. The orphanage requires a higher cost for food and daily need due to the high number of children living in. The orphanage also should be given enough nutrition to 
maintain their health and endurance. Permanent or incidental donors are usually the biggest contributors to cover the cost of consumption. But there is also a social agency that explicitly specifies the donations given only used for consumption or feeding. It was happened in Panti Asuhan Yatim Dhuafa Prambanan as the following statement by the respondent (3rd KI):

".....The donor divided into two, i.e. the permanent donor and incidental donor. The permanent donor is only the Social Government Agency. Their aids used to buy basic need such food." (3rd KI,May 2108)

The priority alternative in the orphanage development fund result (table 3 ) is actually cannot be accepted because of the inconsistency ratio that is higher than equal to 0.10 . There might be several reasons that make it happened. It could be caused by the misunderstanding of the respondent toward the questionnaires, or they might answer the questionnaires in rush and etc. It is concluded based on the clarification of the respondent when the triangulation processed by the researcher.

The most interesting from the finding of this research is that PP Muhammadiyah did not give any regular donation officially to the orphanages' institution after gave waqf land and building. It is because the orphanages should be independent financially and seek the fund source by themselves. There is no donation from muhammadiyah for the institution so far. But a lot of donations and aids gave personally by Muhammadiyah members and Unit Businesses (AUMs) either as incidental donors or as permanent donors.

\section{Strength, Weakness, Opportunity, Threat (SWOT)}

The data obtained from interview, questionnaire, document studies, and observations will describe and analyze from internal factors side as well as external factors using SWOT analysis. It is intended to avoid any threat and to find a potential opportunity that useful for generating the orphanages' income independently.

Table 5 Matrix SWOT of Panti Asuhan Muhammadiyah Sayegan.

\begin{tabular}{|c|c|c|}
\hline Internal Factor & $\begin{array}{l}\text { Strength-S } \\
\text { 1. Foster children's } \\
\text { mentality throught } \\
\text { direct devotion to } \\
\text { society. } \\
\text { 2. Bow making training }\end{array}$ & $\begin{array}{l}\text { Weakness-W } \\
\text { 1. There is no long-term } \\
\text { program } \\
\text { 2. There is no business }\end{array}$ \\
\hline $\begin{array}{l}\text { Opportunity-O } \\
\text { 1. Circular letter to the } \\
\text { society for giving } \\
\text { donation }\end{array}$ & $\begin{array}{l}\text { SO Strategy } \\
\text { Work harder to get more } \\
\text { funds }(\mathrm{S} 2, \mathrm{O} 1)\end{array}$ & $\begin{array}{l}\quad \text { WO Strategy } \\
\text { Run a business from the } \\
\text { available potential (W2, } \\
\text { O1) }\end{array}$ \\
\hline $\begin{array}{l}\text { Threat-T } \\
\text { 1. There is no donation } \\
\text { from PP } \\
\text { Muhammadiyah }\end{array}$ & $\begin{array}{l}\text { ST Strategy } \\
\text { Sell the bow made by } \\
\text { foster children for } \\
\text { additional fund }(\mathrm{S} 2, \mathrm{O} 1)\end{array}$ & \begin{tabular}{l}
\multicolumn{1}{c}{ WT Strategy } \\
Make a business and ask \\
for helping from PP \\
Muhammadiyah $(\mathrm{W} 2, \mathrm{O} 1)$
\end{tabular} \\
\hline
\end{tabular}


Table 6 Matrix SWOT of Panti Asuhan Muhammadiyah Putri Aisyah

\begin{tabular}{|c|c|c|}
\hline Internal Factor & \begin{tabular}{l}
\multicolumn{1}{c}{ Strength-S } \\
1. Good on organization \\
2. Orphanage has a lot \\
assets
\end{tabular} & $\begin{array}{l}\text { Weakness-W } \\
\text { 1. Less of training for } \\
\text { foster children } \\
\text { 2. The staffs are bussy with } \\
\text { their other activities }\end{array}$ \\
\hline $\begin{array}{l}\text { Opportunity-O } \\
\text { 1. Has multipurpose } \\
\text { building which can be } \\
\text { rented } \\
\text { 2. } \begin{array}{l}\text { Orphanages have PAY } \\
\text { Mart and car rent }\end{array} \\
\end{array}$ & $\begin{array}{l}\text { SO Strategy } \\
\text { Expand the business to } \\
\text { property sector. It will not } \\
\text { too hard to do because of } \\
\text { orphanages is well structured } \\
(\mathrm{S} 1,2, \mathrm{O} 2)\end{array}$ & $\begin{array}{l}\text { WO Strategy } \\
\text { Build a building for foster } \\
\text { children training (W1, O2) }\end{array}$ \\
\hline $\begin{array}{l}\text { Threat-T } \\
\text { 1. Variation of culture, } \\
\text { environment }\end{array}$ & $\begin{array}{l}\text { SE Strategy } \\
\text { Build a strong character to } \\
\text { foster children }(\mathrm{S} 1, \mathrm{~T} 1)\end{array}$ & $\begin{array}{l}\quad \text { WT Strategy } \\
\text { Try to spare the time for } \\
\text { caring and giving attention to } \\
\text { foster children }(\mathrm{W} 2, \mathrm{~T} 1)\end{array}$ \\
\hline
\end{tabular}

Panti Asuhan Sayegan (table 5) has to work harder both to establish their own business and start-up the potential they had. On the contrary, Panti Asuhan Muhammadiyah Putri Aisyah (table 6) will have no difficulties to find financial sources since they own some business which well-organized since it was built. However, it still needs to focus on the qualified human resource development and pay attention to the education quality of the orphans. Panti Asuhan Muhammadiyah Putri Aisyah was build based on Al-Ma'un ethos. Therefore, it set not only for feeding and taking-care the orphans but prepares their future financial need by providing the business as income sources.

Table 7 Matrix SWOT of Panti Asuhan Muhammadiyah Prambanan

\begin{tabular}{|c|c|c|}
\hline External Factor & $\begin{array}{l}\quad \text { Strength-S } \\
\text { 1. Innovation in fund rising } \\
\text { 2. Free course program } \\
\text { (English, Sawing, etc) }\end{array}$ & $\begin{array}{l}\text { Weakness-W } \\
\text { 1. Lack of human } \\
\text { resources as teachers } \\
\text { and administrators }\end{array}$ \\
\hline $\begin{array}{l}\text { Opportunity-O } \\
\text { 1. A strong orphanage } \\
\text { alumni association }\end{array}$ & $\begin{array}{l}\text { SO Strategy } \\
\text { The foster children are able } \\
\text { to open a course to get } \\
\text { additional fund and they } \\
\text { could be a tour guide }(S 2, \mathrm{O} 1)\end{array}$ & $\begin{array}{l}\text { WO Strategy } \\
\text { Invite the aluni to become } \\
\text { the caregiver or teacher in } \\
\text { the orphanage }(\mathrm{S} 1, \mathrm{O} 1)\end{array}$ \\
\hline $\begin{array}{l}\text { Theath-T } \\
\text { 1. Pattern of parenting }\end{array}$ & $\begin{array}{l}\text { ST Strategy } \\
\text { Orphanages shuol make a } \\
\text { program relates to parenting } \\
\text { pattern or delegate the adult } \\
\text { foster children to the } \\
\text { parenting training }(\mathrm{S} 2, \mathrm{O} 1)\end{array}$ & $\begin{array}{l}\text { WT Strategy } \\
\text { Maximize the human } \\
\text { resource and train them on } \\
\text { how the good care give is } \\
(\mathrm{W} 1,01)\end{array}$ \\
\hline
\end{tabular}


Panti Asuhan Muhammadiyah Prambanan (Table 7) actually has a potential tourism business prospect in term of location and amount of qualified alumni. As Urie Bronfenbrenner proposed, it will benefit from both if was trained and managed properly due to the environmental systems automatically support them, i.e. the (1) micro-, (2) meso-, (3) exo-, and (4) macro systems. Once they initiate their business (fitted to their strength) in a strategicand well known location, easy to them to be recognized by the public largely. It supports the finding of Andrea \& Mahoney (2017) as a series of four systems nested around a focal individual like a set of concentric circles. So many prospects business they can run, such

Panti Asuhan Muhammadiyah Tuksono (table 8) and Panti Asuhan Naggulan (table 9), Panti Asuhan Muhammadiyah Wates table 10) and Panti Asuhan Muhammadiyah Sudjari (table 11) have to work harder to empower their skill and develop their human resources. They also have to have a good relationship to the macro-level (i.e. Government and PP Muhammadiyah) due to power is the key concept to understand their empowerment process. Power can open their access to the business and industries. The macro power also concerns to empower the grass level to reduce their cost. Therefore, it is important to inform the public about their strengths and weaknesses through any media.

Table 8 SWOT Matrix of Panti Asuhan Muhammadiyah Tuksono

\begin{tabular}{|c|c|c|}
\hline Internal Factor & $\begin{array}{l}\text { Strength-S } \\
\text { 1. Leverage the } \\
\text { opportunities that } \\
\text { exist to establish a } \\
\text { business } \\
\text { 2. Orphanages has } \\
\text { creative ideas and a } \\
\text { passionate board }\end{array}$ & $\begin{array}{l}\text { Weakness-W } \\
\text { 1. The geographical } \\
\text { location is far from } \\
\text { the city } \\
\text { 2. The orphanages are } \\
\text { not too familiar with } \\
\text { the public } \\
\text { 3. Lack of human } \\
\text { resources (officer) }\end{array}$ \\
\hline $\begin{array}{l}\text { Opportunity-O } \\
\text { 1. Have the business in } \\
\text { the form of gas LPG } \\
\text { bases of bright gas, } \\
\text { gallon water refils, } \\
\text { and cooperatives }\end{array}$ & \begin{tabular}{l}
\multicolumn{1}{c}{ SO Strategy } \\
Advance the business to \\
online business system \\
support by the creative \\
ideas they have $(\mathrm{S} 1,2, \mathrm{O} 1)$
\end{tabular} & $\begin{array}{l}\text { WO Strategy } \\
\text { Promote the business into } \\
\text { social media and inform } \\
\text { the exact location (W1,2,3, } \\
\text { O1) }\end{array}$ \\
\hline $\begin{array}{l}\text { Theath-T } \\
\text { 1. Different foster } \\
\text { children's character }\end{array}$ & $\begin{array}{l}\quad \text { ST Strategy } \\
\text { Sell the business item } \\
\text { which is fit to the foster } \\
\text { children character. It must } \\
\text { be interesting and creative } \\
(\mathrm{S} 1,2, \mathrm{O} 1)\end{array}$ & \begin{tabular}{l}
\multicolumn{1}{c}{ WT Strategy } \\
Find another care giver to \\
maintaine the foster \\
children which have \\
different character. So, \\
orphanages will be helpful \\
by the addition caregiver \\
(W3, T1)
\end{tabular} \\
\hline
\end{tabular}


Table 9 SWOT Matrix of Panti Asuhan Muhammadiyah Nanggulan

\begin{tabular}{|c|c|c|}
\hline External Factor & $\begin{array}{l}\text { Strength-S } \\
\text { 1. Orphanages has an application to } \\
\text { facilitate financial reporting } \\
\text { 2. Have sufficient and competent } \\
\text { human resource on social welfare } \\
\text { institution (LKS) } \\
\text { 3. A good development system by } \\
\text { strengthening the institution's } \\
\text { 4. The inventor of financial } \\
\text { application report }\end{array}$ & $\begin{array}{l}\text { Weakness-W } \\
\text { 1. The existence of } \\
\text { rejection from the } \\
\text { surrounding } \\
\text { community in } \\
\text { pioneering } \\
\text { 2. Some of human } \\
\text { resources are still } \\
\text { skill less }\end{array}$ \\
\hline $\begin{array}{l}\text { Opportunity-O } \\
\text { 1. One of the foster } \\
\text { children passed the } \\
\text { PUTM selection } \\
\text { 2. Support from PP } \\
\text { Muhammadiyah in } \\
\text { the development of } \\
\text { financial paging } \\
\text { application } \\
\text { 3. Get A accreditation }\end{array}$ & $\begin{array}{l}\text { SO Strategy } \\
\text { Orphanages should make the long- } \\
\text { term program to maximize the } \\
\text { strength and opportunity they have } \\
(\mathrm{S} 1,2,3,4, \mathrm{I}, 2,3)\end{array}$ & \begin{tabular}{l}
\multicolumn{1}{c}{ WT Strategy } \\
Orphanages should ask \\
PP Muhammadiyah
\end{tabular} \\
\hline $\begin{array}{l}\quad \text { Theath-T } \\
\text { Christianization that can } \\
\text { lead to the transation of } \\
\text { trust }\end{array}$ & $\begin{array}{l}\text { ST Strategy } \\
\text { Orphanage is require to block the } \\
\text { Christianization through invite the } \\
\text { society and held the Islamic study (S2, } \\
3, \mathrm{~T} 1)\end{array}$ & $\begin{array}{l}\quad \text { WT Strategy } \\
\text { Strengthen the care } \\
\text { giver's skill and } \\
\text { people's trust (W2, T1) }\end{array}$ \\
\hline
\end{tabular}

Table 10 SWOT Matrix of Panti Asuhan Muhammadiyah Sudjari

\begin{tabular}{|c|c|c|}
\hline Internal Factor & $\begin{array}{l}\text { Strength-S } \\
\text { 1. Prioritize on alquran } \\
\text { learning }\end{array}$ & $\begin{array}{l}\text { Weakness-W } \\
\text { 1. Less of Tenaga Kerja Sosial } \\
\text { (TKS) either the quantity, } \\
\text { skill or experience } \\
\text { 2. The facility is still not too } \\
\text { good } \\
\text { 3. Less of training for foster } \\
\text { children }\end{array}$ \\
\hline $\begin{array}{l}\text { Opportunity- } \mathbf{O} \\
\text { 1. Maximize the natural } \\
\text { resources around } \\
\text { orphanage to make } \\
\text { handcraft }\end{array}$ & $\begin{array}{l}\text { SO Strategy } \\
\text { Delegate the foster children to } \\
\text { join the tilawah competition } \\
\text { and sell the handcraft to get } \\
\text { additional fund }(S 1,01)\end{array}$ & \begin{tabular}{l}
\multicolumn{1}{c}{ WT Strategy } \\
Train the foster children to \\
make something new from the \\
available natural resources \\
$(\mathrm{W} 3,01)$
\end{tabular} \\
\hline $\begin{array}{l}\text { Theath-T } \\
\text { 1. The outsider children } \\
\text { are not interesting to } \\
\text { go to school }\end{array}$ & $\begin{array}{l}\text { ST Strategy } \\
\text { Make a program that can } \\
\text { influence the outsider to go to } \\
\text { school. The program can be } \\
\text { "belajar alquran keliling" (S1, } \\
\text { T1) }\end{array}$ & $\begin{array}{l}\text { WT Strategy } \\
\text { Invite the outsider to make } \\
\text { handcraft. So that, they can be } \\
\text { maintained easily }(\mathrm{W} 3, \mathrm{~T} 1)\end{array}$ \\
\hline
\end{tabular}


Table 11 SWOT Matrix of Panti Asuhan Muhammadiyah Wates

\begin{tabular}{|c|c|c|}
\hline External Factor & $\begin{array}{l}\text { Strength-S } \\
\text { 1. Support from surrounding } \\
\text { communities } \\
\text { 2. Accepted gracefully on the } \\
\text { establishment of the } \\
\text { orphanage } \\
\text { 3. The burning spirit og the board } \\
\text { 4. The number of boards is quite a } \\
\text { lot }\end{array}$ & $\begin{array}{l}\text { Weakness-W } \\
\text { 1. Lack of training } \\
\text { for the foster } \\
\text { children which is } \\
\text { provided by the } \\
\text { orphanage }\end{array}$ \\
\hline $\begin{array}{l}\quad \text { Opportunity-O } \\
\text { 1. Optimalization of } \\
\text { productive waqf land } \\
\text { with the construction of } \\
\text { multipurpose building }\end{array}$ & $\begin{array}{l}\text { SO Strategy } \\
\text { The orphanage can get easy fund } \\
\text { from the multipurpose building } \\
\text { through rent the building. It will run } \\
\text { easily because of supported by the } \\
\text { burning spirit of the board }(\mathrm{S} 3, \mathrm{O} 1)\end{array}$ & $\begin{array}{l}\quad \text { WT Strategy } \\
\text { The orphanages should } \\
\text { provide and give the } \\
\text { training on waqf } \\
\text { optimazitation for } \\
\text { foster children and } \\
\text { cargiver }(\mathrm{W} 1,01)\end{array}$ \\
\hline $\begin{array}{l}\text { Theath-T } \\
\text { 1. Difficult to get funding }\end{array}$ & $\begin{array}{l}\text { ST Strategy } \\
\text { The orphanage has to utilize the } \\
\text { number of boards they have to get } \\
\text { funding. In addition, orphanages } \\
\text { can cooperate with the society to } \\
\text { ease the fund seeking }(\mathrm{S} 4, \mathrm{~T} 1)\end{array}$ & $\begin{array}{l}\quad \text { WT Strategy } \\
\text { The orphanage has to } \\
\text { create more training } \\
\text { and invite the expert } \\
\text { on fund raising aspect } \\
(\mathrm{W} 1, \mathrm{~T} 1)\end{array}$ \\
\hline
\end{tabular}

\section{Conclusion}

Observation and research that have been done are about self-reliance hierarchy of the Muhammadiyah orphanage for several months, which the result can be concluded as follows: 1). Muhammadiyah orphanages around D.I.Yogyakarta province have the same priority funding sources which describe as follows: permanent donors, incidental donors, social and government service, durable businesses, and seasonal businesses. 2). The funds also were allocated for the same purposes which the priority as the foster children's skill improvement, the foster children's tuition fee, orphanages development fund, orphanage activities, kitchen support (consumption)/daily needs, orphanage's savings/investment and Foster children's saving and investment. 3 ). The finding indicates that four out of seven orphanages funds for the foster children's skill improvement. The rest is used for the orphanage development fund, followed by the purpose of foster children's saving/investing. Panti Asuhan Muhammadiyah Tuksono, Panti Asuhan Yatim Dhuafa Prambanan, and Panti Asuhan Ahmad Sudjari spend the funds mostly for the foster children's skill improvement. While the Panti Asuhan Muhammadiyah Wates's main priority is the orphanages development fund. Panti Asuhan Muhaammadiyah Nanggulan's main priority is the foster children's saving/investment. 4). The top prior donor that suggested by any programs and criteria in the analysis is the permanent donor. 


\section{Utami, Azhari, Sawarjuwono, \& Alhadi \\ Social Fund and The Hierarchy of Muhammadiyah Orphanages Financial Independency}

\section{Recommendation}

This research suggests that the orphanage's potential should be maximized as high as possible. The existing potential can be developed into a profitable and sustainable business. Therefore, the orphanages are able to create welfare for foster children. The orphanages are required to be strongly independent from various aspects, mostly in the financial aspect. The dependent of foster children to the orphanage can be reduced by creating the independence environment and empowering them with skill and financial management training that can be started in the early stage. A specification skill is needed by each orphanage among skill they have. It means the orphanage can develop the prior potential they have and execute it as a representing business unit to support the orphanage economy. There are some topics research areas that potential to investigate by further researcher i.e: a). The orphanage's model of empowerment and financial independence; b). How to promote a certified and qualified orphanage management system.

\section{Acknowledgements}

I would like to thank to my research assistant Azmi, who has huge dedication to assist me in collecting data; and to my supervisors Prof. Tjiptohadi and Prof Abu Azam who provides their continuous critics and brilliant ideas to improve this paper so that eligible to read. This paper would not complete without respondents' pleasures and welcomes during observation, interview, and triangulation. Therefore, a pray to all of them, May what they did for orphanage will grant reward from Allah Subhanahuwata'ala, God Almighty; and May they grant a power to create a financial independency in running the orphanage.

\section{References}

Abror, R. H. (2012). Rethinking Muhammadiyah: Masjid, Teologi Dakwah dan Tauhid Sosial (Persepktif Filsafat Dakwah). Jurnal Ilmu Dakwah, 6(1), 53-75. https://doi.org/10.15575/idajhs.v6i1.327

Cresswell, J. W. (2007). Quallitative Inquiry \& Research Design Choosing Among Five Approaches. USA: SAGE Publication.

Dona, R. (2017). Pengenalan Multifactor Evaluaton Process (MFEP) dan Analytic Hierarchy Process. 3.

Ettekal, A. \& Mahoney, J. L. (2017). The SAGE Encyclopedia of out-of School Learning: Ecological System Theory. Thousand Oak: SAGE.

Harker, P. T. (1987). Alternative Modes of Questioning in the Analytic Hierarchy Process. Math Modelling, 9(3-5), 353-360.

Huttman, E., \& Redmond, S. (1992) Women and Homelessness: Evidence of Need to Look Beyond Shelters to Long Term Social Service Assistance and Permanent Housing. The Journal of Sociology \& Social Welfare, 19(4), 7.

https://scholarworks.wmich.edu/issw/vol19/iss4/7

Lexy, J. M. (2009). Metode Penelitian Kualitatif. Bandung: PT. Remaja Rosdakarya.

Ommani, A. R. (2011). Strengths, Weaknesses, Opportunities and Threats (SWOT) Analysis for Farming System Businesses Management: Case of Wheat Farmers of Shadervan 
District, Shoushtar Township, Iran. African Journal of Business Management, 5(22), 9448-

9454. Retrieved from: http://www.academicjournals.org/AJBM

Qodir, Z. (2008). Muhammadiyah dan Advokasi Kemiskinan. Lariba Jurnal Ekonomi Islam, 141. https://journal.uii.ac.id/JEI/article/view/166/131

Rizki, M. (2018). Muhammadiyah Canangkan Pemberdayaan Panti Asuhan. Retrieved from: http://www.tribunnews.com/nasional/2102/08/07/muhammadiyahCanangkanPemberdayaan-Panti-asuhan (November 27, 2012)

Saaty, T. L. (2001). Decision Making with the AHP: Why is the Principal Eigenvector Necessary. European Journal of Operational Research, 145(1), 85-91. https://doi.org/10.1016/s0377-2217(02)00227-8

Silvia, A., \& Permana, B. (2018). Strategi Peningkatan Pendanaan Mandiri Panti Asuhan melalui Pelatihan Sablon. Syukur (Jurnal Inovasi Sosial dan Pengabdian Masyarakat), 1(1), 12-21. https://doi.org/10.22236/syukur_vol1/is1pp12-21

Suara Muhammadiyah. Sertifikasi Aset dan Wakaf Jadi Prioritas Majelis Wakaf dan Kehartabendaan. Suara Muhammadiyah: 25. Retrieved from: http://www.suaramuhammadiyah.id/2016/09/03/sertifikasi-aset-dan-wakaf-jadiprioritas-majelis-wakaf-dan-kehartabendaan/ (2016, September 16)

Suparno, (2017). Community Participation and The Creation of Social Justice. International Journal of Civil Engineering and Technology (IJCIET), 8(8), 1093-1098. Retrieved from: http://http://www.iaeme.com/ijciet/issues.asp?JType=IJCIET\&VType=8\&IType= $\underline{8}$

Taylor, S. J., Bogdan, R., \& Devault, M. (2016). Introduction to Qualitative Research Methods: A Guidebook and Resource, 4th Edition. Hoboken, New Jersey: John Wiley \& Sons.

Teehankee, B. (2009). The Analytic Hierarchy Process: Capturing Quantitative and Qualitative Criteria for Balanced Decision-Making. National Conference of the OR Society of the Philliphines (ORSP). Philliphines. Retrieved from: https://www.researchgate.net/publication/256009323 The Analytic Hierarchy Pro cess Capturing Quantitative and Qualitative Criteria for Balanced DecisionMaking

Wahyuningtias, C. N., Sudarmiatin, \& Indrawati, A. (2016). SWOT Analysis for Determining Marketing Strategy at the Primagama Courses. IOSR Journal of Business and Management (IOSR-JBM), 18(5), 38-46. Retrieved from: http://www.iosrjournals.org/iosr$\mathrm{jbm} /$ papers/Vol18-issue5/Version-3/G1805033846.pdf

Yüksel, I. (2012). Developing a Multi-Criteria Decision Making Model for PESTEL Analysis. International Journal of Business and Management, 7(24), 52-66. https://doi.org/10.5539/ijbm.v7n24p52 